\title{
Cross-reactivity of pollen and food allergens: soybean Gly $m 4$ is a member of the Bet $v 1$ superfamily and closely resembles yellow lupine proteins
}

\author{
Paul Rösch ${ }^{1 *}$, Hanna Berkner ${ }^{1}$, Philipp Neudecker ${ }^{1}$, Diana Mittag², Barbara Ballmer-Weber ${ }^{2}$, Peter Lehn ${ }^{3}$, \\ Kristian Schweimer ${ }^{1}$, Stefan Vieths ${ }^{4}$
}

From Food Allergy and Anaphylaxis Meeting 2011

Venice, Italy. 17-19 February 2011

In many cases, patients allergic to birch pollen also show allergic reactions after ingestion of plant-derived food. This observation is explained on the molecular level by cross-reactivity of IgE antibodies induced by sensitization to the major birch pollen allergen Bet $\mathrm{v} 1$ with homologous food allergens. As IgE antibodies recognize conformational epitopes, a precise structural characterization of the allergens involved is necessary to understand cross-reactivity and thus to develop new methods of allergen-specific immunotherapy for allergic patients. Here we present the three-dimensional solution structure of the soybean allergen Gly $\mathrm{m} 4$, a member of the superfamily of Bet $\mathrm{v} 1$ homologous proteins and a cross-reactant with IgE antibodies originally raised against Bet $\mathrm{v} 1$, as shown by immunoblot inhibition and histamine release assays. Although the overall fold of Gly $\mathrm{m} 4$ is very similar to that of Bet $\mathrm{v} 1$, the threedimensional structures differ in detail. The Gly $m 4$ local structures that display those differences are also found in proteins from yellow lupine. The three-dimensional structure of Gly $\mathrm{m} 4$ in combination with immunological data allows us to propose surface patches that might represent cross-reactive epitopes.

\section{Author details}

${ }^{1}$ Universität Bayreuth, Biopolymere, Bayreuth, Germany. ${ }^{2}$ University Hospital, Dermatology, Zürich, Switzerland. ${ }^{3}$ Universitätsklinikum Regensburg, Klinische Chemie und Laboratoriumsmedizin, Regensburg, Germany. ${ }^{4}$ Paul-EhrlichInstitut, Allergologie, Langen, Germany.

'Universität Bayreuth, Biopolymere, Bayreuth, Germany

Full list of author information is available at the end of the article
Published: 12 August 2011

doi:10.1186/2045-7022-1-S1-P6

Cite this article as: Rösch et al:: Cross-reactivity of pollen and food allergens: soybean Gly $\mathrm{m} 4$ is a member of the Bet $\mathrm{v} 1$ superfamily and closely resembles yellow lupine proteins. Clinical and Translational Allergy 2011 1(Suppl 1):P6.
Submit your next manuscript to BioMed Central and take full advantage of:

- Convenient online submission

- Thorough peer review

- No space constraints or color figure charges

- Immediate publication on acceptance

- Inclusion in PubMed, CAS, Scopus and Google Scholar

- Research which is freely available for redistribution

Submit your manuscript at www.biomedcentral.com/submit
() Biomed Central 